\title{
Analysis of the occurrence of wildfires in the Iberian Peninsula based on harmonised data from national forest inventories
}

\author{
Leónia Nunes $^{1,2}$ (1) Juan Álvarez-González ${ }^{3} \cdot$ Iciar Alberdi $^{4} \cdot$ Vasco Silva $^{1} \cdot$ Marta Rocha $^{1} \cdot$ Francisco Castro Rego $^{1}$
}

Received: 1 February 2018 / Accepted: 18 February 2019 / Published online: 12 March 2019

(C) INRA and Springer-Verlag France SAS, part of Springer Nature 2019

\begin{abstract}
- Key message Every year, about 280,000 ha of forest area burn in the Iberian Peninsula. Both countries national forest inventories were harmonised to provide consistent results of the influence of forest stand structure on fire probability. Results show that basal area and vertical structure variables are associated with fire probability; however, that association varies with forest composition. Deciduous oaks and pine forests showed opposite tendencies. Forest management could be oriented considering these results.

- Context Fuel variables, in particular the ones that characterise stand vertical structure, are extremely important to determine the occurrence and severity of fire. However, documentation on fire occurrences and stand characteristics is still scarce in southern Europe. - Aims In this study, we analyse the stand and structure variables from National Forest Inventories (NFIs) in order to identify the important ones that are associated with the presence/absence of wildfires in the Iberian Peninsula.

- Methods A harmonised database including a characterization of the vertical structure of the stand and its species composition was obtained by combining data from NFIs from Spain and Portugal and data from burned areas that occurred between 2005 and 2015. - Results Stand characteristics results show that the plots that were later burned have lower average stand basal area. For deciduous oaks, more canopy cover has less probability to burn, and for all the other oaks, in different degrees, more understory cover has higher probability to burn. Regarding pine species, more canopy cover has lower probability to burn.

- Conclusion The results indicate important associations between stand variables and the presence/absence of wildfires that could support the forest management with the objective of reducing the probability of forest fires.
\end{abstract}

Keywords Wildfire $\cdot$ Vertical structure $\cdot$ Portugal $\cdot$ Spain $\cdot$ Harmonised Forest Inventory data

Handling Editors: Tuula Packalen and Klemens Schadauer

This article is part of the topical collection on Forest information for bioeconomy outlooks at European level

Leónia Nunes

lnunes@isa.ulisboa.pt

1 Centre for Applied Ecology "Professor Baeta Neves" (CEABN), InBIO, School of Agriculture, University of Lisbon, Tapada da Ajuda, 1349-017 Lisbon, Portugal

2 CITAB, Centre of the Research and Technology of Agro-Environmental and Biological Science, University of Trás-os-Montes and Alto Douro, Qta. de Prados, 5000-801 Vila Real, Portugal

3 Departamento de Ingeniería Agroforestal, Escuela Politécnica Superior de Ingeniería, Universidade de Santiago de Compostela, Campus Universitario s/n, 27002 Lugo, Spain

4 INIA-CIFOR, Dpto, Selvicultura y Gestión de los Sistemas Forestales, Ctra. La Coruña km. 7.5, 28040 Madrid, Spain

\section{Introduction}

\subsection{Forests in Spain and Portugal}

Forest land in Spain occupies 18.418 million hectares (36.9\% of total land) and the other wooded land 9.208 million hectares (FOREST EUROPE 2015a). Forest area has been increased, since 1990 , by 4.608 million hectares due to several factors but, especially, to agricultural land abandonment. Spain has four eco-regions: Alpine, Atlantic, Mediterranean and Macaronesia. This fact implies great species diversity with very different stand structure. Coniferous and broadleaf forests account for similar amounts of forested area in Spain (6.8 and 10.0 million hectares, respectively) while mixed forest covers 1.4 million hectares (FOREST EUROPE 2015a). The forest types having an area greater than 1 million hectares are the holm oak forest (Quercus ilex L. s.l.), dehesas and other agrosylvopastoral systems, aleppo pine forest (Pinus 
halepensis Mill.), scots pine forest (Pinus sylvestris L.) and the mixed autochthonous broadleaves and coniferous forests of the Mediterranean biogeographical region (Spanish Forest Map 1997-2006, 1:50,000).

Forests in Portugal occupy $35.3 \%$ of the territory, about 3.182 million hectares, a percentage in accordance with the average value of the EU27, 37.9\% under State of Europe's Forests (SOEF) Report 2015 (FOREST EUROPE 2015a). A characterization of forestry evolution in Portugal, including the reforestation state subsidised programs that occurred from the 1930s onwards, was made by Tomé et al. (1999). As a consequence, the forest area almost doubled in the last century. According to the last inventory (ICNF 2013), the most important tree species in Portugal are Eucalyptus globulus Labill. (812,000 ha), Quercus suber L. (737,000 ha) and Pinus pinaster Aiton (714,000 ha) with around $72 \%$ of the total forest area.

The major concerns for the future of the forest and forestry sector in the Iberian Peninsula are wildfires, rural abandonment (emigration to the cities that lead to forsake management practices), global climate change, the loss of forest biodiversity and desertification (INE 2001; do Rosário 2004; DGRF 2006; Pereira et al. 2006b; FOREST EUROPE 2015b; MAGRAMA 2015). Forest wildfires are a matter of concern in forest management and in the protection of natural resources. The burned area of stands and shrubs in 2017 was about 442,000 ha in Portugal (ICNF 2017) and 178,000 ha in Spain (MAPAMA 2017a).

\subsection{National Forest Inventory (NFI)}

National Forest Inventories (NFIs) provide one of the best large-scale sources of information and have had an expansion to include new variables to meet increasing information requirements. This need regarding wood stocks and areas of major forest species provided the impetus to undertake the first NFIs in the Iberian Peninsula. Recently, the NFIs also provide information on key aspects of forest resources, wood availability, carbon storage, vitality and forest biodiversity (ICNF 2013; IEPNB 2016).

The Spanish National Forest Inventory (SNFI) covers all forest land in Spain. The First SNFI1 (1965-1974) was based on aerial photograph interpretation and around 65,000 temporary plots were measured using Bitterlich sampling. Although the initial objective was to have a 10 -year cycle between NFIs, the second SNFI2 did not start until 1986 due to national circumstances. From the second cycle onwards, the plots are permanent, enabling stratification and comparisons to be undertaken (Alberdi Asensio et al. 2010). Sample plots are established at the intersections of a 1-km $\times 1-\mathrm{km}$ UTM grid. Since the Third SNFI3, forest area and strata estimation are described prior to the NFI using the National Forest Map (Alberdi et al. 2016). Although the primary objectives were the estimation of forest area and growing stock, the current aim of the SNFI is to provide information at national and regional levels about the state and evolution of forests through the analysis of growing stock, carbon pools, development of forest resources, forest health, risks and forest biodiversity (Alberdi et al. 2017).

The Portuguese National Forest Inventory (PTNFI) was started in 1965 and covers the entire territory of mainland Portugal. The first PTNFI1 was carried out during the years 1965 and 1966 as a result of a common interest of the Portuguese National Forest Service and the pulp and paper industries to obtain data on growing stocks and their distribution, mainly for $P$. pinaster and E. globulus. The main objective of the PTNFI2 was to update the information related to all the sampled stands of $P$. pinaster and E. globulus. The PTNFI3 took place between the years 1980 and 1989 by the National Forest Services in collaboration with the Portuguese Association of the Pulp and Paper Industries to update information on the area and standing volumes for all the country and particularly to P. pinaster and E. globulus stands and to evaluate the structure and the health conditions of $Q$. suber and evergreen oaks (Quercus L. spp.) forests. The need for more recent forest information due to forest wildfires and eucalyptus area expansion led to the realization of the PTNFI4, which took place between 1990 and 1999 and was conducted in two phases (Barreiro et al. 2010): (a) In phase 1, the $P$. pinaster and the E. globulus stands were inventoried to estimate the volume for both species and (b) phase 2 aimed to update the information resulting from the previously collected inventory and to incorporate analysis on the Portuguese forest biodiversity as a consequence of the recommendations from the Third Ministerial Conference on the Protection of Forests in Europe (MCPFE 2003a), which was held in Lisbon in 1998. The PTNFI5 took place between 2005 and 2006 and had the objective to update the area, forest stand composition and standing volume due to the vast area affected by wildfires of 2003 and 2005 (AFN 2010). The inventory was carried out in cooperation with the Portuguese Association of the Pulp and Paper Industries and incorporated additional variables to provide information on sustainable forest management indicators (MCPFE 2003b). The latest NFI (PTNFI6) had as objective to update information produced on the previous one in terms of growing stock volume and biomass, sequestered carbon, cork, cone and resin production and biodiversity indicators. This inventory took place between 2010 and 2015, and the preliminary results are available on ICNF (2013).

\subsection{Wildfires in the Iberian Peninsula}

Historically, fire was an important element for the ecosystem dynamics in the Mediterranean landscapes (Keeley et al. 2012) and represented a major element in many forested 
ecosystems (González et al. 2006), particularly in the Southern Europe, where rural communities learned how to use it as a land management tool. However, on the second half of the twentieth century, with the depopulation of rural areas, wildfires increased in area in the Iberian Peninsula and forest fires became one of the main environmental problems and one of the most important natural hazards (Pereira et al. 2006a; San-Miguel-Ayanz et al. 2013). Although quite different in size of territory and population, Portugal and Spain share similar environmental conditions and fire propensity. Therefore, the phenomena of large fires in the Iberian Peninsula, in particular its behaviour, needs to be treated as a whole.

According to the data in the European Forest Fire Information System (EFFIS) (http://effis.jrc.ec.europa.eu/), about 20,000 ignitions occurred in Portugal between 2005 and 2014 with a burned area of about 104,000 ha (Fig. 1). The scenario in Spain during the same period was not very different. An average of 15,000 fires occurs in Spain every year, burning approximately 108,000 ha (MAPAMA 2017b). Between 2001 and 2010, nearly a third (389,000 ha) of the burnt area was forest (MAPAMA 2017c).

The necessity to improve the national fire management systems is important in both countries in order to reduce the number of fires and the burned area as a consequence of these catastrophic wildfires in the Iberian Peninsula (Rego et al. 2013; SanMiguel-Ayanz et al. 2013). Moreover, it is essential to have a fire risk assessment model to weigh forest management options with respect to the fire risk issues (González et al. 2006).

\subsection{The role of NFI on fire assessment}

Fires occur because of a combination of predisposing weather, fuel conditions and ignition agents, resulting this last one from human activities or natural events (Lavorel et al. 2007). The behaviour of a wildfire can be predicted by the stand forest characteristics collected on NFIs and have been explored by several authors (Lentile et al. 2006; Fernandes 2009; Alvarez et al. 2012; Fernández-Alonso et al. 2013).

In a first approach, using simulations, some studies found that forest inventory data was helpful in fuel modelling (Cruz et al. 2003), hazard classification and mapping (Hardy et al. 2001). Fernandes et al. (2006) build a set of fuel models for forest types defined as a combination of overstorey species dominance and stand structure using forest inventory data in Portugal. The forest classification in the Portuguese NFI was translated into fuel models, which were used to evaluate and compare the fire hazard potential between and within forest types defined by their composition and structure. These authors found that potential fire behaviour is primarily driven by stand structure, rather than by cover type. In a later study and using the same data, Fernandes (2009) examined the hypothesis of whether standard forest inventory data could be used to assess fire hazard. González-Ferreiro et al.
(2017) used data from the Fourth Spanish National Forest Inventory (SNFI4) to model the vertical profile of canopy fuels loads, with stand variables as predictors, in pure and even-aged $P$. pinaster and Pinus radiata D. Don stands in Galicia (north-western Spain). In this study, dominant height was the main predictor for both species and when other predictor variables were also included in models, only quadratic mean diameter for $P$. pinaster and stand basal area for $P$. radiata significantly improved the results obtained with dominant height. Other studies also considered density and height as potential predictors of fire type (Alvarez et al. 2012; Fernández-Alonso et al. 2013).

In a second approach, based on the estimation of fire probability, González et al. (2006) presented a model for the probability of fire occurrence in forest stands in Catalonia (northeastern Spain). This model was developed based on data from the SNFI2 and perimeters of the forest fires that occurred in Catalonia during a 12-year period that followed the SNFI2 measurement. These authors hypothesised that by decreasing stand density, removing low canopy layers and favouring hardwood, the forest manager may decrease the probability of fire damage and make it easier to extinguish the fire.

In our study, we used the second approach to understand if the characteristics of the stands, collected or derived from the NFIs, are associated with the probability of fire occurrences in the Iberian Peninsula.

Accurate knowledge of the relationship between forest characteristics and the occurrence of wildfires is essential, and the information in the NFIs is the only currently available regarding forest characteristics and distribution at national scale. Therefore, studies aimed to relate the variables of the NFI with potential wildfires are required to establish fuel treatment priorities and evaluate the effectiveness of fuel management actions (Keane et al. 2001). The objectives of this work were threefold (i) to analyse the history and the development of the NFIs in Spain and Portugal since the first inventories in the two countries in order to select the stand characteristics that are related with wildfires and to identify the reasons underlying the field collection of the parameters related with wildfires, (ii) to identify the important stand variables from Spain and Portugal NFIs that are associated with the presence/absence of wildfires in the Iberian Peninsula and (iii) to analyse the stand vertical structure and to evaluate their impact on the fire occurrence.

\section{Material and methods}

\subsection{Analysis of the history and the development of the NFI in Spain and Portugal}

Research on the two countries NFIs was conducted in order to analyse the purpose of each inventory, the field variables collected, evolution of their integration and the reasons behind 
a)

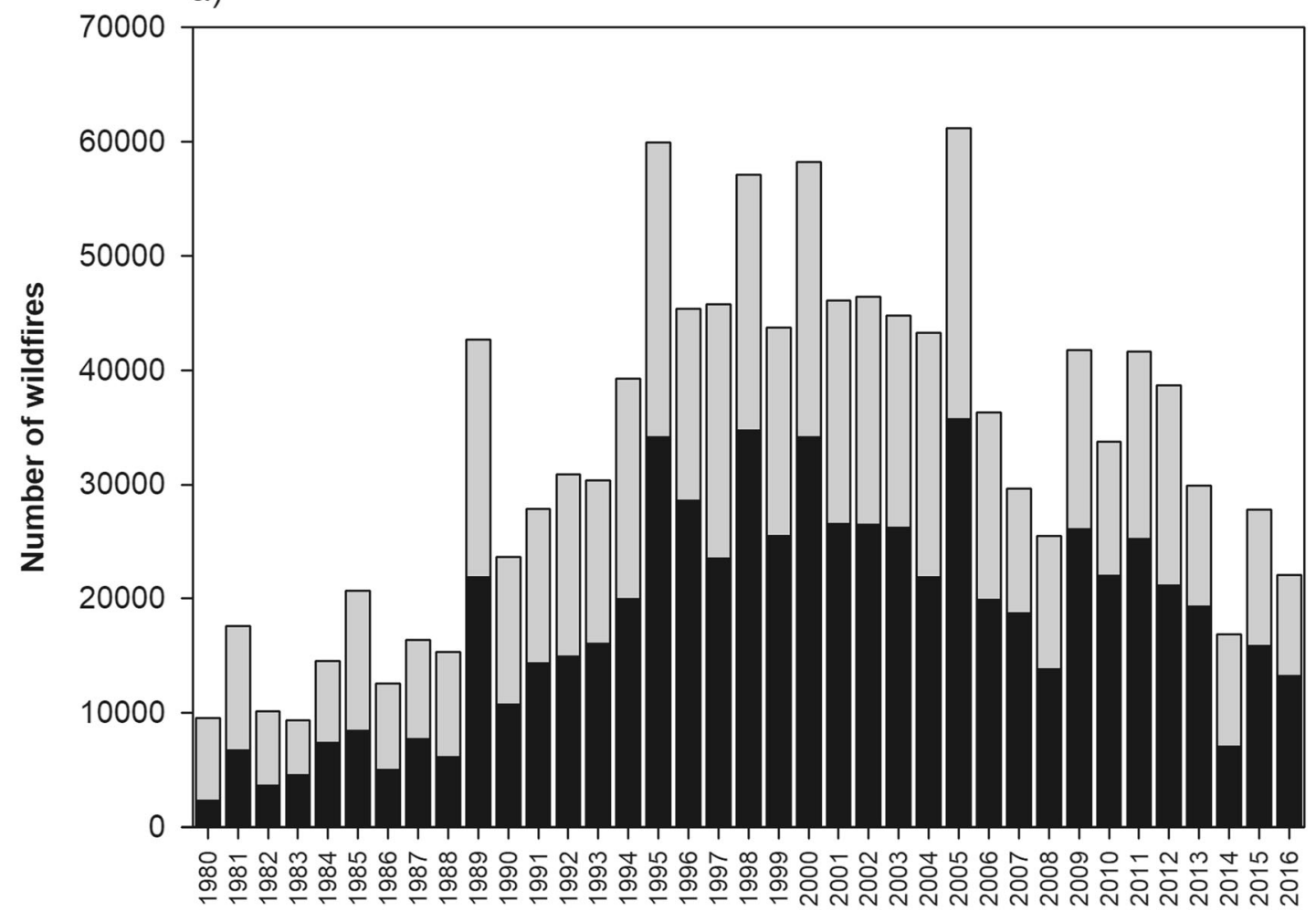

b)

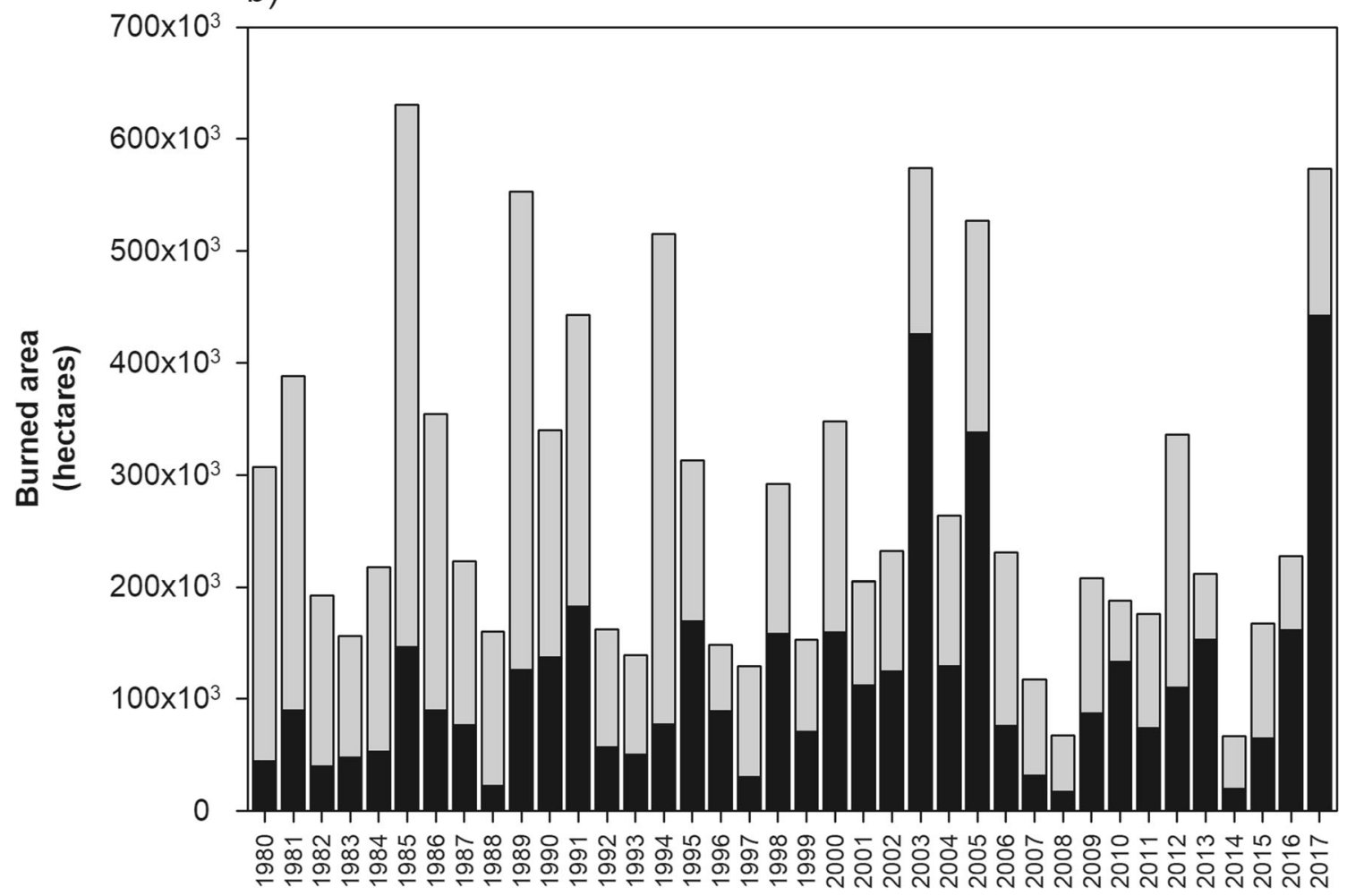

Portugal Spain 
Fig. 1 a Number of wildfires (1980-2016) and b burned areas (1980 2017) in Spain and Portugal. Dataset from http://effis.jrc.ec.europa.eu/. Burned area for Portugal in 2017 from ICNF (2017)

these trends. Table 1 presents a summary of Spain and Portugal NFIs in terms of the sampling method, field plots and the maps that support the analysis of field work. In Portugal were analysed publications and final reports available on the Portuguese National Forests Services library (DGSFA 19651966, 1966, 1968, 1971, 1985, 1989, 1990, 2001; AFN 2009; ICNF 2013) and also information available on the website related with the most recent inventories (http://www2.icnf.pt/ portal/florestas/ifn). For Spain, the digital information available on the website of the Spanish National Forest
Inventory was used (http://www.mapama.gob.es/es/ biodiversidad/servicios/banco-datos-naturaleza/informaciondisponible/index_inventario_forestal.aspx). All the variables collected on each inventory were listed, and a selection of which variables were important to fuel modelling was carried out. These variables were organised in three groups, (i) timber and cork production, (ii) fire and (iii) biodiversity, and then were recorded in the years where the collection took place.

The analysis reveals that in the NFIs, with time, occurred changes either in their objectives or in the collection of data. Table 2 indicates that the NFIs have been augmented to include new variables to meet increasing information requirements, such as the ones to estimate biodiversity indicators and fire assessment. The early inventories focused their action and data on

Table 1 Summary of the National Forest Inventories in Spain and Portugal

\begin{tabular}{|c|c|c|c|c|c|c|c|}
\hline $\begin{array}{l}\text { Spain } \\
\text { Inventory }\end{array}$ & Year & Based on & $\begin{array}{l}\text { Sampling } \\
\text { method and field } \\
\text { plots }\end{array}$ & $\begin{array}{l}\text { Portugal } \\
\text { Inventory }\end{array}$ & Year & Based on & $\begin{array}{l}\text { Sampling } \\
\text { method and } \\
\text { field plots }\end{array}$ \\
\hline \multirow[t]{2}{*}{ SNFI1 } & \multirow[t]{2}{*}{ 1965-1974 } & \multirow[t]{2}{*}{$\begin{array}{l}\text { Estimation of forest areas using } \\
\text { a systematic sampling grid, } \\
\text { overlaid on aerial } \\
\text { photographs (scale } \\
\text { 1:30,000) }\end{array}$} & \multirow{2}{*}{$\begin{array}{l}\text { Stratified double } \\
\text { sampling } \\
\text { design with } \\
\text { optimal } \\
\text { allocation of } \\
\text { plots; } \\
\text { temporary } \\
\text { plots }\end{array}$} & PTNFI1 & 1965-1965 & $\begin{array}{l}\text { North: panchromatic aerial } \\
\text { photography from } 1963 \text { to } \\
1965 \text { (scale } 1: 15,000 \text { ) } \\
\text { South: agricultural and forestry } \\
\text { areas map }\end{array}$ & $\begin{array}{l}\text { Stratified } \\
\text { sampling } \\
\text { strategy; } \\
\text { temporary } \\
\text { plots }\end{array}$ \\
\hline & & & & PTNFI2 & 1968-1980 & $\begin{array}{l}\text { North: new aerial photography } \\
\text { South: new infrared aerial } \\
\text { photography (scale } \\
1: 15,000)\end{array}$ & $\begin{array}{l}\text { Stratified } \\
\text { sampling } \\
\text { strategy: } \\
\text { temporary } \\
\text { plots }\end{array}$ \\
\hline \multirow[t]{2}{*}{ SNFI2 } & \multirow[t]{2}{*}{ 1986-1996 } & \multirow[t]{2}{*}{$\begin{array}{l}\text { Forest areas and strata were } \\
\text { identified from the existing } \\
\text { agriculture and land use } \\
\text { map. }\end{array}$} & \multirow[t]{2}{*}{$\begin{array}{l}\text { Systematic } \\
1-\mathrm{km} \times 1-\mathrm{km} \\
\text { grid; } \\
\text { permanent } \\
\text { plots }\end{array}$} & PTNFI3 & 1980-1981 & $\begin{array}{l}\text { New aerial photography } \\
\text { coverage of the country } \\
\text { For the regions analysis, a } \\
\text { panchromatic aerial } \\
\text { photography from } 1986 \text { was } \\
\text { used. }\end{array}$ & $\begin{array}{l}\text { Stratified } \\
\text { sampling } \\
\text { strategy; } \\
\text { temporary } \\
\text { plots }\end{array}$ \\
\hline & & & & PTNFI4 & 1990-1999 & $\begin{array}{l}\text { Phase 1. 1990: aerial } \\
\text { photography from } 1990 \text { on } \\
\text { false colour infrared film to } \\
\text { produce the land use } \\
\text { cartography (scale } \\
\text { 1:25,000). Phase } 2.1995: \\
\text { aerial photography } \\
\text { production; 1996-1997: } \\
\text { photo-interpretation and ar- } \\
\text { ea evaluation }\end{array}$ & $\begin{array}{l}\text { Stratified } \\
\text { sampling } \\
\text { strategy; } \\
\text { temporary } \\
\text { plots }\end{array}$ \\
\hline SNFI3 & 1997-2007 & $\begin{array}{l}\text { Stratification was 'a } \\
\text { posteriori'. Land cover } \\
\text { classification and forest area } \\
\text { estimation were based on } \\
\text { digital maps (scale 1:50000) } \\
\text { and ortho-images. }\end{array}$ & $\begin{array}{l}\text { Same systematic } \\
\text { grid as SNFI2; } \\
\text { permanent } \\
\text { plots }\end{array}$ & PTNFI5 & 2005-2016 & $\begin{array}{l}\text { New aerial photography from } \\
2004,2005 \text { and } 2006 \\
\text { covering the whole country }\end{array}$ & $\begin{array}{l}\text { Systematic } \\
2 \mathrm{~km} \times 2 \\
\mathrm{~km} \text { grid; } \\
\text { permanent } \\
\text { location } \\
\text { plots }\end{array}$ \\
\hline SNFI4 & 2008-ongoing & $\begin{array}{l}\text { Stratification was 'a } \\
\text { posteriori'. Land cover } \\
\text { classification and forest area } \\
\text { estimation were based on } \\
\text { new digital maps (scale } \\
\text { 1:25000) and ortho-images. }\end{array}$ & $\begin{array}{l}\text { Same systematic } \\
\text { grid as SNFI3; } \\
\text { permanent } \\
\text { plots }\end{array}$ & PTNFI6 & 2014-2015 & $\begin{array}{l}\text { Digital ortho-photo maps of } \\
1995,2005 \text { and } 2010 \\
(500 \mathrm{~m} \times 500 \mathrm{~m} \text { grid })\end{array}$ & $\begin{array}{l}\text { Same } \\
\text { systematic } \\
\text { grid as } \\
\text { PTNFI5; } \\
\text { permanent } \\
\text { location } \\
\text { plots }\end{array}$ \\
\hline
\end{tabular}




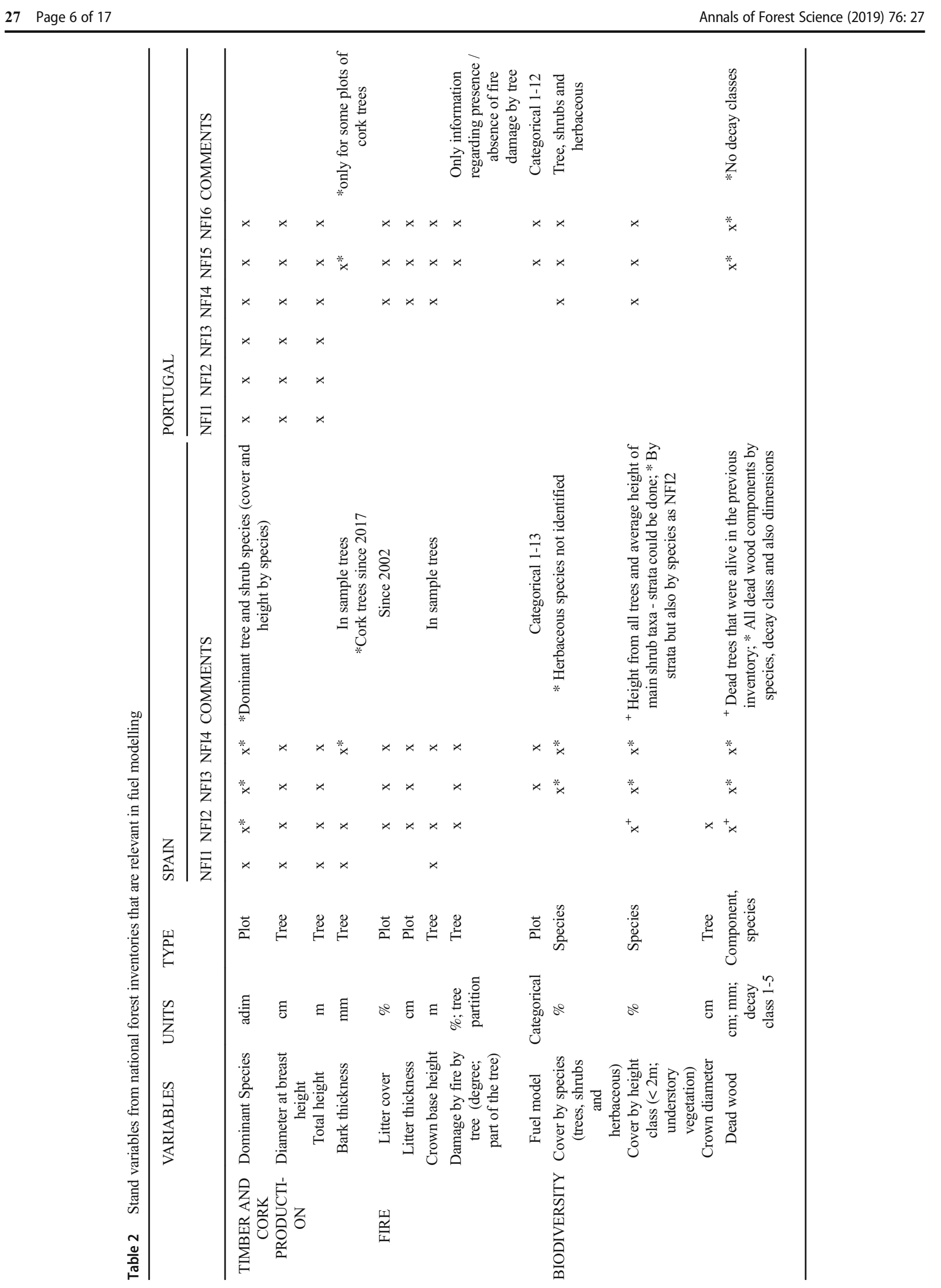

Q SPringer 
wood stocks and areas of major forest species whereas the latest inventories provide also information on sustainable ecosystem indicators that include new variables that support forest management (Tomppo et al. 2010) as well as information on forest resources for establishing policies, plans and projects and for international reporting purposes (e.g. Forest Resources Assessment, Forest Europe, State of Europe's Forests, United Nations Framework Convention on Climate Change). In Spain, due to the increasing national and international forest information requirements, the number of measured variables and objectives was broadened, including vertical structure. New methodologies were developed taking into consideration the national forest characteristics, the information requirements but also the National Forest Inventories harmonisation initiatives (Vidal et al. 2016; Alberdi et al. 2017). New field assessments related to vertical structure stands in Portugal started in PTNFI4 as a consequence of recommendations from the Third Ministerial Conference of the Protection of Forest in Europe which considered of major importance an analysis of the Portuguese forest biodiversity. Since then, most of the sustainable forest management indicators established in Lisbon (1998) and Vienna (2002) (MCPFE 2003a) are still being estimated.

\subsection{Stand variables collected in the NFIs useful to assess fire probability}

Apart from conventional NFI variables such as diameter at breast height, total height, standing volume and density, other variables that provide information regarding biodiversity indicators are useful to assess fire behaviour models, mainly those linked to the vertical structure of the stands that can be easily retrieved from NFI data. In order to assess wildfire occurrence in the Iberian Peninsula, a harmonised methodological process was carried out in the frame of the H2020 DIABOLO project (http://diabolo-project.eu/) to achieve a common database structure for NFI stand data, taking into account harmonised tree species. Data from forest stands used in this work were obtained from the SNFI3 (1997-2007) and from the PTNFI5 (2005-2006).

SNFI3 established around 95,000 permanent field plots in all forest land consisting of four concentric circular fixed areas with radius of $5,10,15$ and $25 \mathrm{~m}$. Data collection can be categorised into three main classes: stand description, measured tree data and biodiversity assessment. Tree saplings, regeneration and shrub species are recorded in the $5 \mathrm{~m}$ radius subplot. PTNFI5 used a systematic sampling design done from a regular grid of $0.5 \times 0.5 \mathrm{~km}$, covering the whole country (used for photo-interpretation), that originates other grids of higher order with $2 \times 2 \mathrm{~km}$ and $4 \times 4 \mathrm{~km}$ for field work in forests and shrubs, respectively. The systematic grid covers all land classes. Field plots, in a total of 12,258, are circular areas of $2000 \mathrm{~m}^{2}$ for $Q$. suber and Q. ilex s.l. and of $500 \mathrm{~m}^{2}$ for all other dominant species.
In both inventories, the following data were recorded for each sample tree: species, diameter at breast height, height, abundance as well information regarding the structure of the species through the different canopy layers. Forest plots were identified as the ones with more than 0.5 ha with trees higher than $5 \mathrm{~m}$ and a canopy cover of more than $10 \%$, in accordance with forest definition of the Food and Agriculture Organization of the United Nations (FAO 2004). The final database that was used in this analysis has a total of 60,607 inventory plots from Spain and 7935 inventory plots from Portugal, measured over the whole Iberian Peninsula. Data from the Macaronesia Region (Canary, Azores and Madeira islands) were not considered in this study.

Variables selected from plot data were stand basal area (BA, $\mathrm{m}^{2} \mathrm{ha}^{-1}$ ), dominant height (Hdom, $\mathrm{m}$ ), defined as the mean height of the 100 thickest trees per hectare, and density by species $\left(\mathrm{n} \mathrm{ha}^{-1}\right)$, whereas those related with trees were diameter at breast height $(\mathrm{DBH}, \mathrm{cm})$, total height $(\mathrm{H}, \mathrm{m})$, crown base height $(\mathrm{CBH}, \mathrm{m})$ or crown length $(\mathrm{CL}, \mathrm{m})$, and vertical structure. Other stand variables useful to complete the fuelbed information were litter thickness (m) and litter cover (\%).

A common methodology was applied to NFI data of both countries in order to assess the percentage of cover by species (tree and shrubs). Countries have different field methodologies to collect these data, and the threshold of the vertical structure height classes is different. We propose a harmonisation process to establish the percentage of cover by species, tree and shrubs, by height classes with a total of seven strata of multiple heights (DGF 1999). These thresholds are commonly used in studies of other biological groups, such as bird communities across Europe, orchids and insects in South America (e.g. Watt 2004; Confalonieri and Neto 2012; Pedroso-de-Moraes et al. 2015). The same tree or shrub can be part of different height classes, seven height strata in total (h1 > 16 m, h2 [8-16 m[, h3 [4-8 m[, h4 [2-4 m[, h5 [1-2 m[, h6 [0.5-1 m[, h7 <0.5 m), but no stratum can have more than $100 \%$ of forest cover. In Spain, we developed models to estimate the crown base height and the crown width of each species using information from four sample trees systematically selected on each sample plots of the SNFI2 to complete a database with more than 255,000 sample trees covering the distribution area of all the forest species. Then, the estimates of these variables were used to classify the trees in the seven height strata. Moreover, crown cover and average height of every shrub species were recorded in the $5 \mathrm{~m}$ subplots in the SNFI3. Then, these measures were used to classify the shrubs species in each stratum. In Portugal, the vertical structure was assessed by the cover percentages for each of the three most abundant species (tree or shrub) per height class.

From a total of 34 and 33 trees species or tree groups inventoried from Spain and Portugal, respectively, an aggregation taking into account main tree species led to a final set of 16 trees or tree groups: P. pinaster, P. halepensis, Pinus pinea L., $P$. sylvestris, other pines, other conifers, $Q$. ilex s.l., 
Quercus faginea Lam., Q. suber, Quercus robur L., Quercus pyrenaica Willd., other oaks, Eucalyptus L'Hér. spp., Castanea sativa Mill., Fagus sylvatica L. and other broadleaves. The nomenclature of species is in accordance with Flora iberica (Castroviejo et al. 2015).

\subsection{Burned areas in the Iberian Peninsula}

The period 2005-2015 was selected in order to allow an adequate temporal proximity to the NFI data of both countries (SNFI3, 1997-2007 and PTNFI5, 2005-2006) where almost all the field work was done previously to 2005 . The fire dataset, which includes wildfires recorded in Portugal and Spain, was retrieved from the European Fire Database provided by the European Forest Fire Information System (EFFIS). The forest fire information is derived from the daily processing of MODIS satellite imagery at $250 \mathrm{~m}$ ground spatial resolution, where burnt scars of approximately 30 ha in size are mapped. Although only a fraction of the total number of fires is mapped, the area burned by fires of this size represents about 75 to $80 \%$ of the total area burned in the EU (SanMiguel-Ayanz et al. 2012). For the analysis purposes, we used the dataset as a vector layer in ESRI Shapefile format.

\subsection{Data analysis}

The database included all harmonised data from Spain and Portugal NFIs. Data were analysed taking into account the following variables: density (number of trees per hectare), basal area $\left(\mathrm{m}^{2} \mathrm{ha}^{-1}\right)$, dominant height $(\mathrm{m})$, average height $(\mathrm{m})$, quadratic mean diameter at breast height $(\mathrm{cm})$, litter cover (\%) and the percentage of cover of each species in a plot per class height (h1-h7). A comparison of two means with Student's $t$ test was applied to identify the important stand variables that are associated with presence/absence of wildfire in the Iberian Peninsula for each of the 16 classes associated with the dominant tree species or groups of species.

Analyses of the vertical structure and the total coverage of the stands were done to understand the behaviour of the species through the different strata in two situations: burned plots and plots that were later burned.

All statistical analyses were performed using procedures of the IBM SPSS Statistics (version 23). The identification of the plots that were later burned was done by intersecting the burned areas with the NFI plots, using Geographic Information Software QGIS, in a common coordinate reference system (ETRS89). A binary categorical variable was then created, equalling 0 if the plot was not burned later and 1 if the plot was burned later at least one time. Based on the wildfire characteristics in the Iberian Peninsula and also in the knowledge from field experts on wildfire behaviour, we assumed that all the plots that were located inside a burned area were burned.

\section{Results}

In Portugal, 1396 out of 7935 sample plots of the PTNFI5 were burned (18\%) at least one time, whereas in Spain, only 1093 out of 60,607 sample plots of the SNFI3 were burned (2\%). P. pinaster $(5.9 \%)$ and Eucalyptus spp. (6.0\%) are the species with the highest percentage of burned plots for the Iberian Peninsula (Fig. 2). In Portugal, the $12 \%$ and $10 \%$ of the burned plots corresponds to $P$. pinaster and Eucalyptus spp. plots, respectively, whereas in Spain, the percentage of burned plots for the same species is $34 \%$ and $11 \%$, respectively. These plots are located mainly in the Galicia region of Spain and in the centre and north of Portugal (Fig. 3). In fact, Portugal had an area affected by wildfires in 2005 of around 338,000 ha (Fig. 1). Between 1990 and 2007, the percentage of burned area for these same species was approximately $26 \%$ for P. pinaster and $11 \%$ for Eucalyptus spp., accordingly with the results from Fireland Project (CEABN 2013). In Spain, during the period from 2001 to 2010 , the highest percentages of burned area by species corresponded to P. pinaster (27\%), E. globulus (14\%) and P. halepensis (11\%) (MAPAMA 2017c).

Stand variables from Spanish and Portuguese NFIs (basal area, density, quadratic mean diameter and dominant height) were analysed in order to identify those that are associated with presence/absence of wildfire on the NFI plots for a period of 10 years (2005-2015) (Fig. 4). Low values of stand basal area tend to be associated to plots with high probability of burning. The only exceptions are for $Q$. suber and, to a lesser extent, for $Q$. faginea. The average stand basal area of the plots that were later burned was significantly lower than those of the unburned plots $(P<0.01)$ for $P$. pinaster and the other conifers, for the deciduous oaks, $Q$. robur and $Q$. pyrenaica, and for Eucalyptus spp. (Fig. 4a). The lower value of average stand basal area of the $P$. pinaster and Eucalyptus spp. plots that were burned later is associated with lower quadratic mean diameters and not with lower density, whereas for the deciduous oaks, $Q$. robur and $Q$. pyrenaica, lower stand basal area is much more associated with lower density of those plots than with differences in quadratic mean diameter (Fig. 4b, c). For Q. suber, the situation is a little more complex. The plots that were later burned have higher stand basal area than nonburned plots as the higher density of trees in pre-fire plots is more influential on stand basal area than smaller quadratic mean diameters. For $C$. sativa, the statistical differences between unburned and plots that were later burned are observed in the dominant height $(P<0.01)$ as the unburned plots tend to have taller dominant trees and denser stands (Fig. 4d). A deeper look into this question and a better understanding of the processes involved are possible by using the information of the vertical structure of the stands (Fig. 5) taking into account the seven height layers' strata (h1-h7). The burning probability and fire spread on pines, well-illustrated by 
Fig. 2 Percentage of burned NFIs plots in Iberian Peninsula per species or group of species

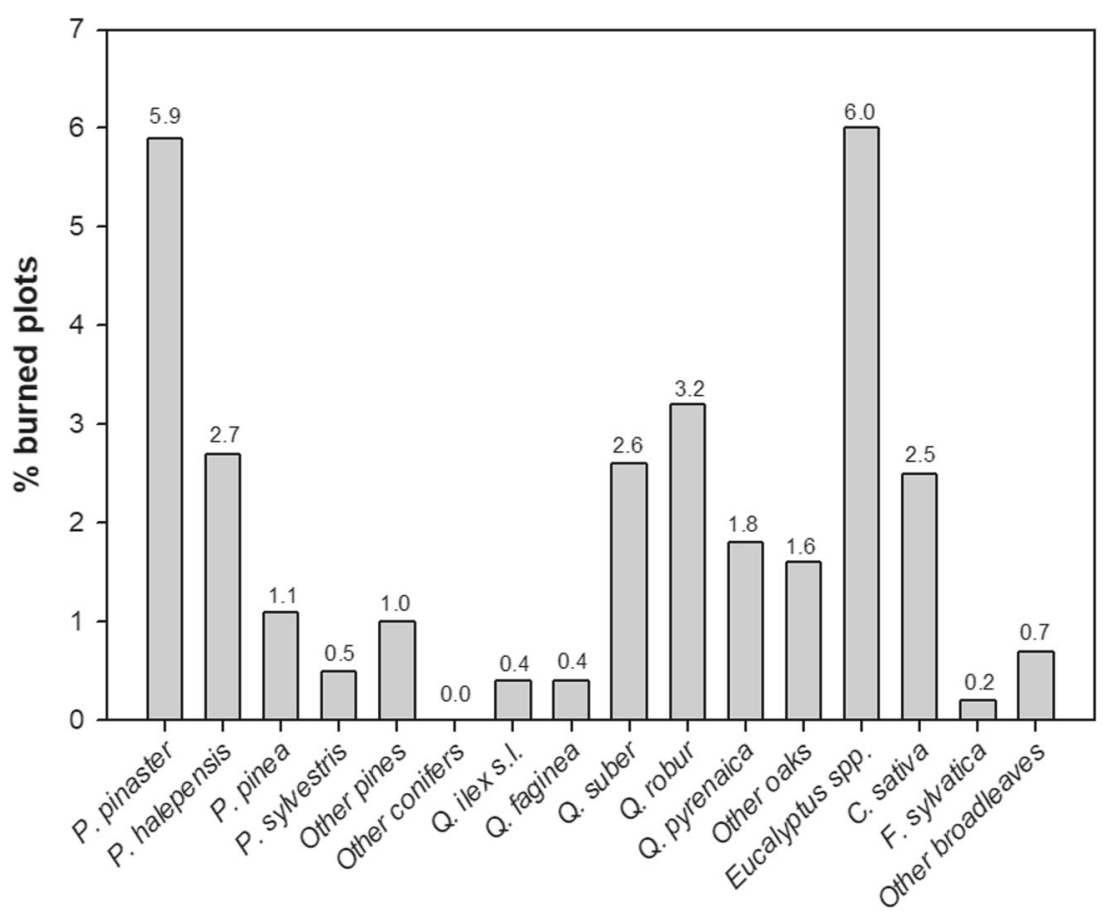

$P$. pinaster, is associated with pre-fire characteristics of lower values of stand basal area and quadratic mean diameters, to not only lower canopy cover (lower cover values for layers h1 to h4) but also higher cover values for the understory layers h5 to h7, which are more associated with fire probability and spread (Fig. 5a). For oaks, two different situations occur: on one hand, for the smaller evergreen oaks, well illustrated by $Q$. suber, the plots that were later burned have higher values of stand basal area and density, with higher cover values for the understory layers h5 to h7 (Fig. 5b), and therefore, the evergreen crowns that burn well are closer to each other and to the ground which is a factor favouring burning probability and fire spread; on the opposite side, we have unburned plots more associated with low density and larger quadratic mean diameters. The $Q$. robur and $Q$. pyrenaica plots that were later burned have low values of stand basal area and density with higher values for understory cover layers h5 to h7. For Eucalyptus spp. and C. sativa, the plots that were later burned have lower stand basal area and smaller quadratic mean diameters, which is reflected in lower cover in all strata of the vertical structure (Fig. 5c). No burned plots were identified in the Other conifers neither Other broadleaves plots.

\section{Discussion}

\subsection{Fuel variables from National Forest Inventories}

Nowadays, the information on the characteristics of the vertical structure of forests, canopies and understory can be easily retrieved from the NFIs. NFIs have been integrating more information on variables used for fuel modelling in Portugal and Spain since the 1990s. Current fire behaviour models require information on the several structure variables, and some studies have addressed the importance of stand structure as the main driver of fire vulnerability (Keyes and O'Hara 2002; Fernandes 2009). In fact, NFIs are important tools to provide information on status and trends on a variety of parameters describing forests and forest uses and represents the most complete spatial distribution of many stand and tree variables (ICNF 2013; Álvarez-González et al. 2014; Alberdi et al. 2017). Nevertheless, information about vertical structure of forests is often collected in a non-harmonised way across countries, situation that compromises the comparability and reinforces the need to develop harmonised methodologies for assessing fuel loads in the vertical strata. The harmonised NFI data serve both national and international reports and take into account the requirements and recommendations of national and international agreements (MCPFE 2003b, e.g. a; Vidal et al. 2016) that can be used to support fuel management programs at European scale (ICNF 2013; Álvarez-González et al. 2014; Alberdi et al. 2017).

\subsection{Occurrence of wildfires in Iberian Peninsula based on harmonised NFI information}

Some studies in Europe have related the stand characteristics with the crown fire potential (Fernandes 2009; RuizGonzález and Álvarez-González 2011; Fernández-Alonso 

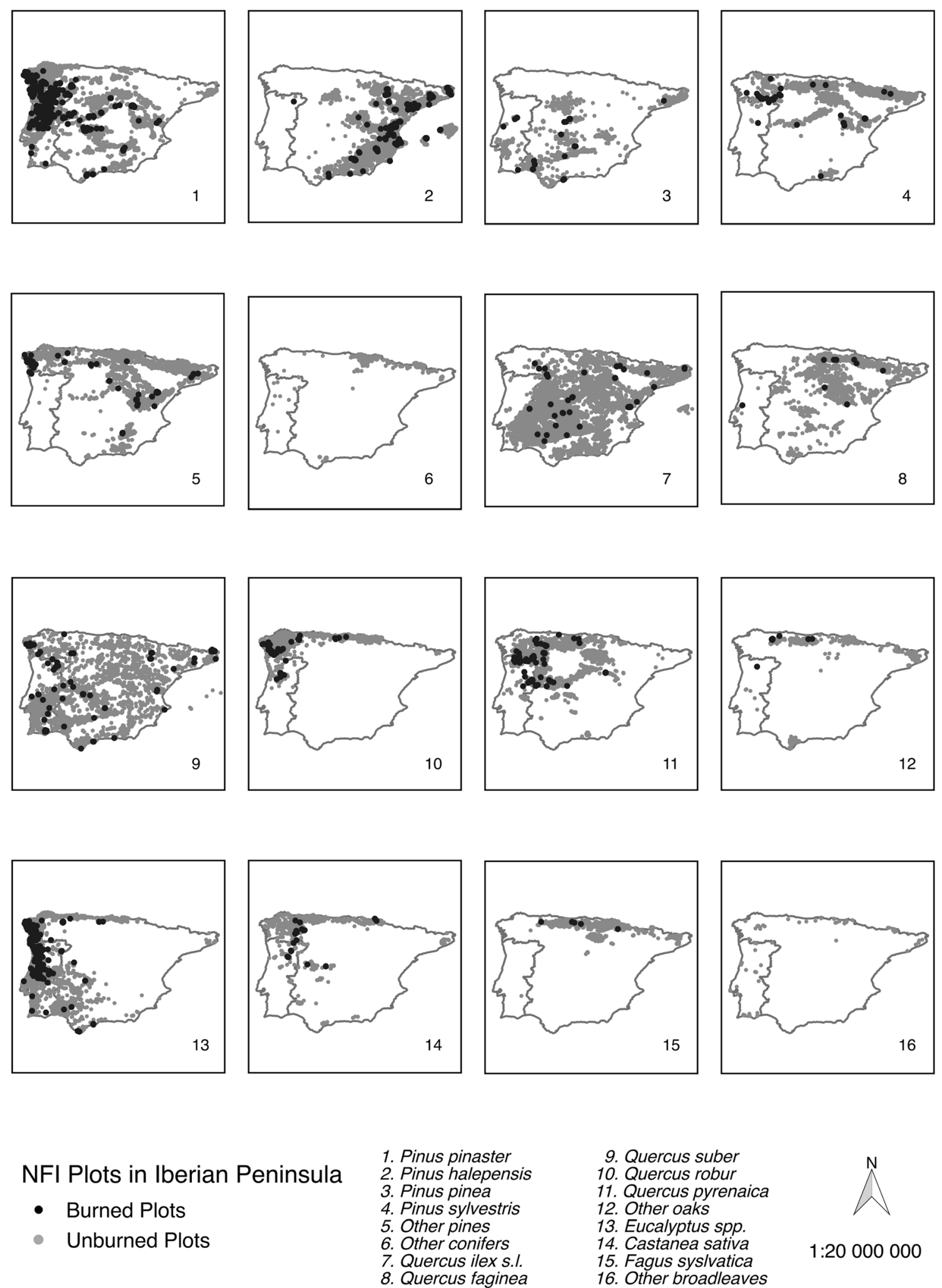

$1: 20000000$

Fig. 3 Location of unburned plots and plots that were later burned in the Iberian Peninsula NFIs for each species or group of species

et al. 2013; Gómez-Vázquez et al. 2014; GonzálezFerreiro et al. 2017), but only a few with fire probability (González et al. 2006; Silva et al. 2009).
Even species composition of the stand is also a variable to take into account in fire occurrences (González et al. 2006), some studies found stand structure more important 

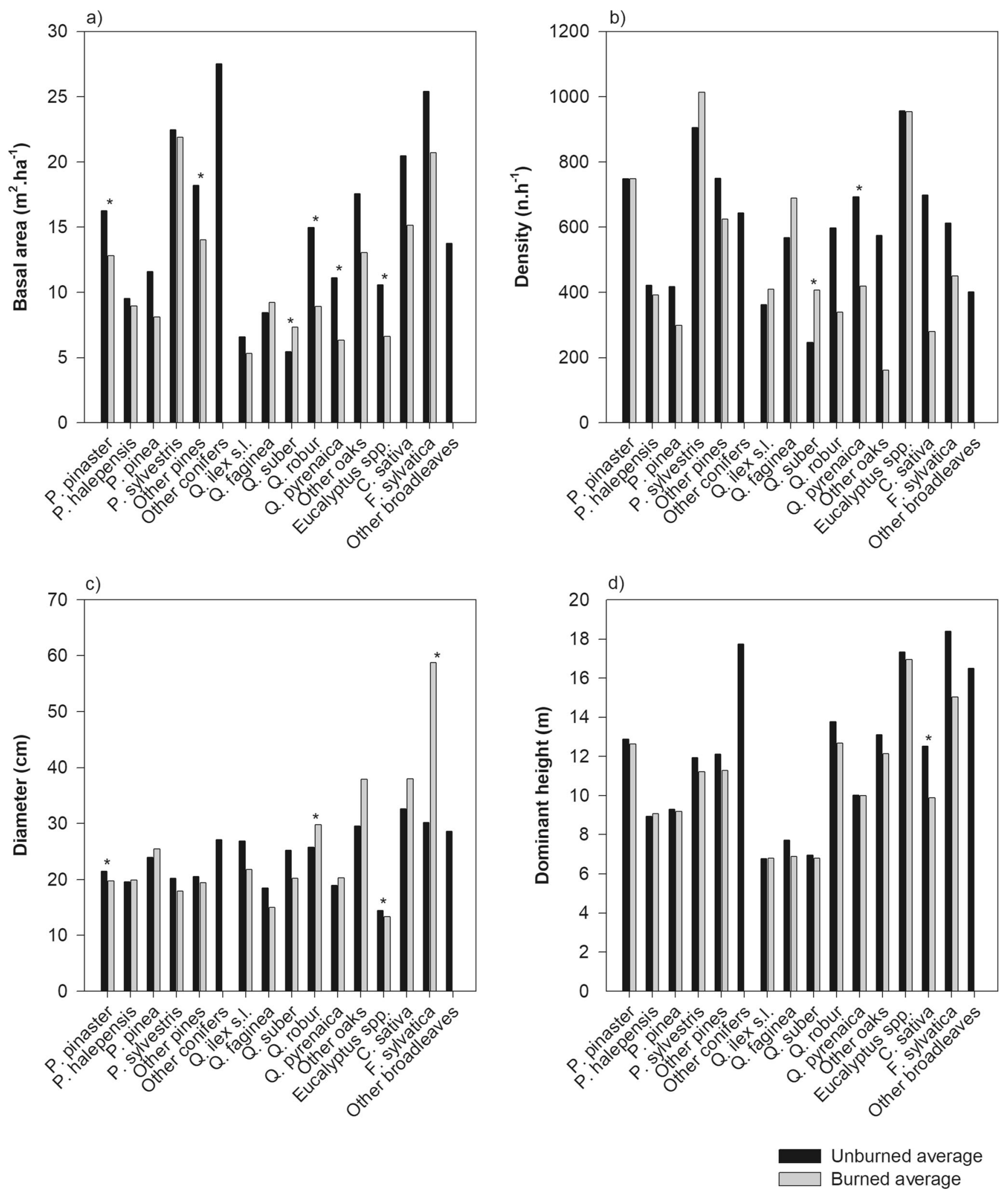

Fig. 4 Average values of the main stand characteristics of unburned plots and plots that were later burned by species or groups of species in the Iberian Peninsula (a stand basal area, b density, c quadratic mean

diameter, $\mathbf{d}$ dominant height). Asterisks indicate significant differences between unburned plots and plots that were later burned $(P<0.05)$ 
a)
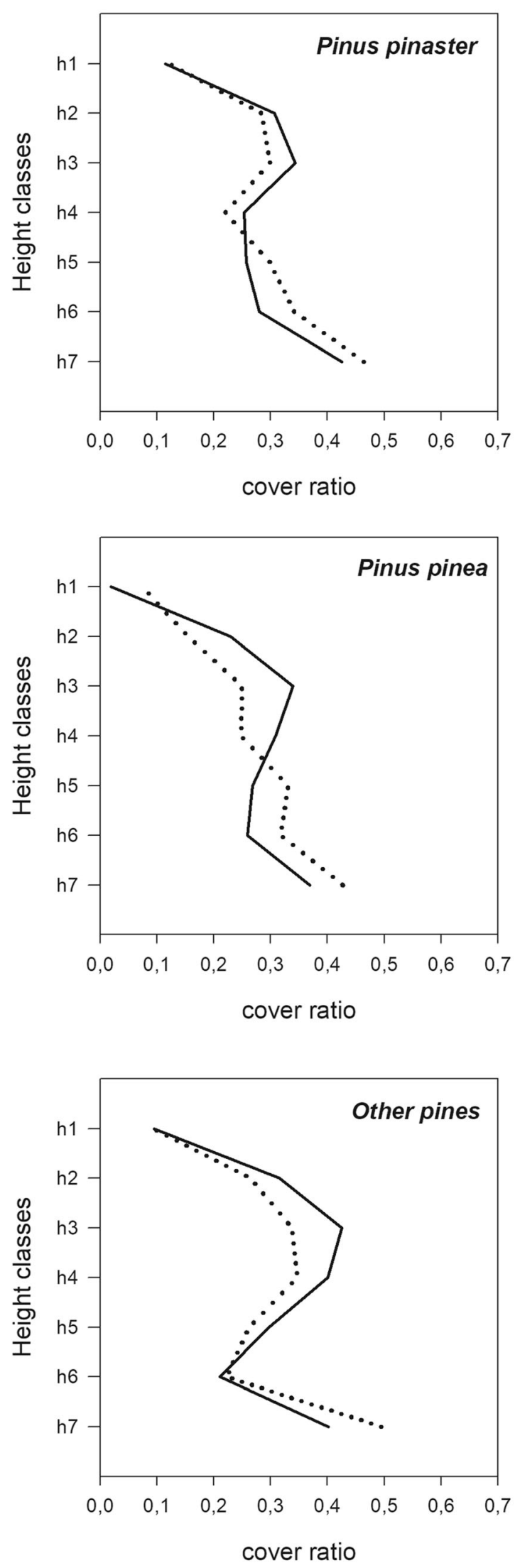
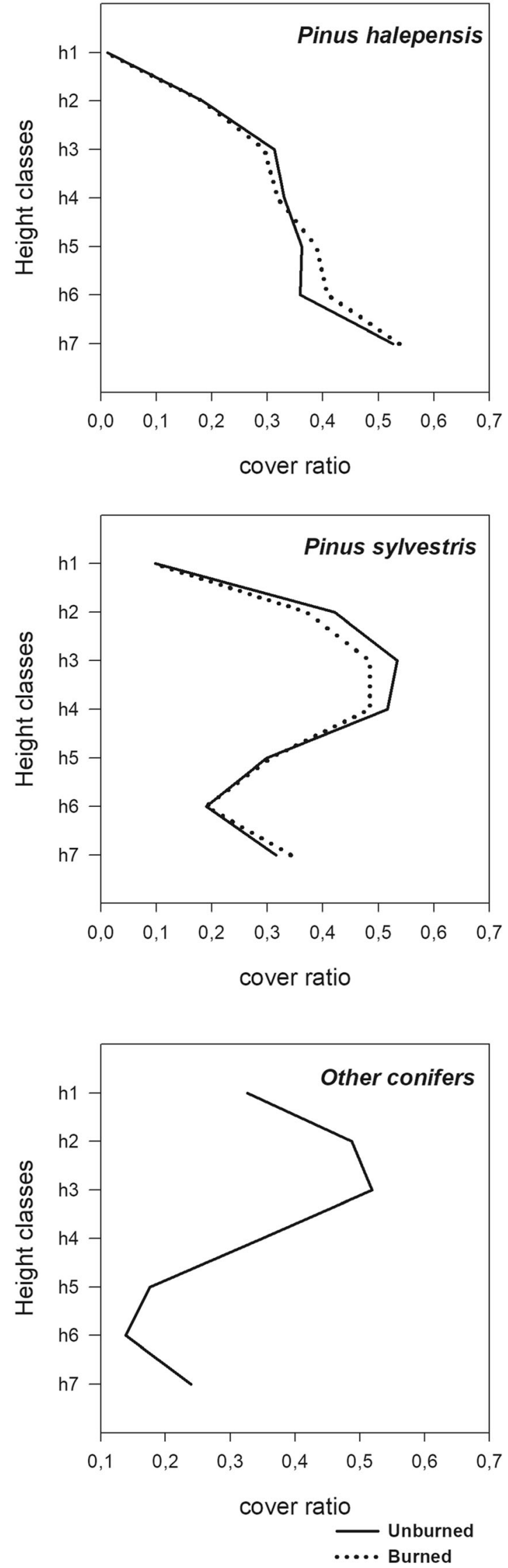
Fig. 5 Total cover ratio by height class for each species or group of species in the Spanish and Portuguese NFIs. Continuous line corresponds to unburned plots whereas dotted line corresponds to plots that were later burned (a conifers species, $\mathbf{b}$ oak species, $\mathbf{c}$ other species). The seven height classes are distinguished as follows: $\mathrm{h} 1>16 \mathrm{~m}, \mathrm{~h} 2$ [8$16 \mathrm{~m}[$, h3 [4-8 m[, h4 [2-4 m[, h5 [1-2 m[, h6 [0.5-1 m[ and h7 < $0.5 \mathrm{~m}$

to fire behaviour than the tree species that comprise the stand (Fernandes et al. 2006). Our results demonstrated benefits on using information both in stand variables and stand vertical structure to assess the fire occurrence in NFIs stands.

Basal area is the stand characteristic that has shown to have a clear effect on the occurrence of wildfires on the Iberian Peninsula. These results are consistent with those reported by Fernández-Alonso et al. (2013), who estimates the canopy fuel characteristics in relation to crown fire potential in pine stands in north-western Spain and found that stand basal area was the most important variable for estimating canopy fuel loads and canopy bulk density. Also, González-Ferreiro et al. (2017) found that stand basal area was an important variable to estimate the vertical profiles of canopy fuels in $P$. radiata stands in north-western Spain.

The probability of forest stands to become affected by forest wildfire in the Iberian Peninsula, according to our results, increases with decreasing stand basal area, except for $Q$. suber, and with increasing percentage of cover of shrub species. Also, the general trend in most analysed species to burn when dominant height is lower seems intuitive. However, the interpretation of the results of stand basal area seems counterintuitive. This might occur since lower stand basal area allows for more understory development which, in turn, makes fire occurrence and spread easier. At first glance, it could be hypothesised that stands with higher values of basal area would have higher probability of burning as they have higher canopy biomass and higher proximity between tree crowns allowing an easier propagation of fire. In fact, it appears that the opposite conclusion applies, except for $Q$. suber and Q. faginea.

The joint interpretation of stand variables and vertical structure results allows for a better understanding of the processes involved. At the same time, information on stand vertical structure and its connection with fire occurrence is important to support management decisions on each fuel strata, surface, ladder and canopy fuel, which affect the fire behaviour the most. For instance, the unburned plots of $Q$. suber are associated with low density and larger quadratic mean diameters, as in mature "dehesas" known to be much less susceptible to burn, consistent with a previous study by Pollet and Omi (2002) who reported that stands resembling mature sparse forests have a lower fire risk than dense and multi-layered stands. On the other hand, for the taller deciduous oaks, as $Q$. robur and $Q$. pyrenaica, the plots that were later burned have low values of stand basal area, reflecting low density, in spite of large quadratic mean diameters. This is in association with higher values for understory cover that are more fire prone. Closed canopies of deciduous trees have higher foliar moisture and are therefore less prone to sustain wildfire spread.

The results highlight the importance of knowledge of stand characteristics and its structure that have more influence in fire occurrence. This knowledge is crucial for establishing silvicultural strategies that takes into consideration the risk of fire (González et al. 2006; Botequim et al. 2017) in order to design stand-level fuel treatments to lower fire occurrence. Also, understanding the stand variables more associated with fire occurrence in connection with information from the structure of the stands serves as a diagnostic of the hazardous forest areas with the need of urgent interventions and changed management strategies.

The NFI harmonisation process is an important and necessary tool to disseminate data that enables comparative analyses to be performed at the European scale (Winter et al. 2008; Tomppo et al. 2010; Vidal et al. 2016). This work used a methodology to harmonise the vertical structure analysis between the two countries that could be applied to other countries with common problems, and they should be treated as a whole. Other parameters such as climate, dead wood and other variables from NFIs could be included in a further analysis.

\section{Conclusions}

In this study, we used harmonised data from Spain and Portugal NFIs to identify the influence of forest characteristics on fire occurrence. This harmonised NFIs information provides an outstanding database in terms of size and representation of forests in both countries. Further studies regarding the influence of forest fuels composition and their spatial structure on the transition from surface to crown fire and on fire severity based on the NFI information would be recommended. Also, analyses of the proximity between stands and their probability to burn could contribute to include spatial patterning in this process and in the development of integrated fire probability models. Future steps should include post fire conditions and satellite data allowing for a more detailed information on the severity and areas burned, providing an opportunity to a deeper analysis. 
b)
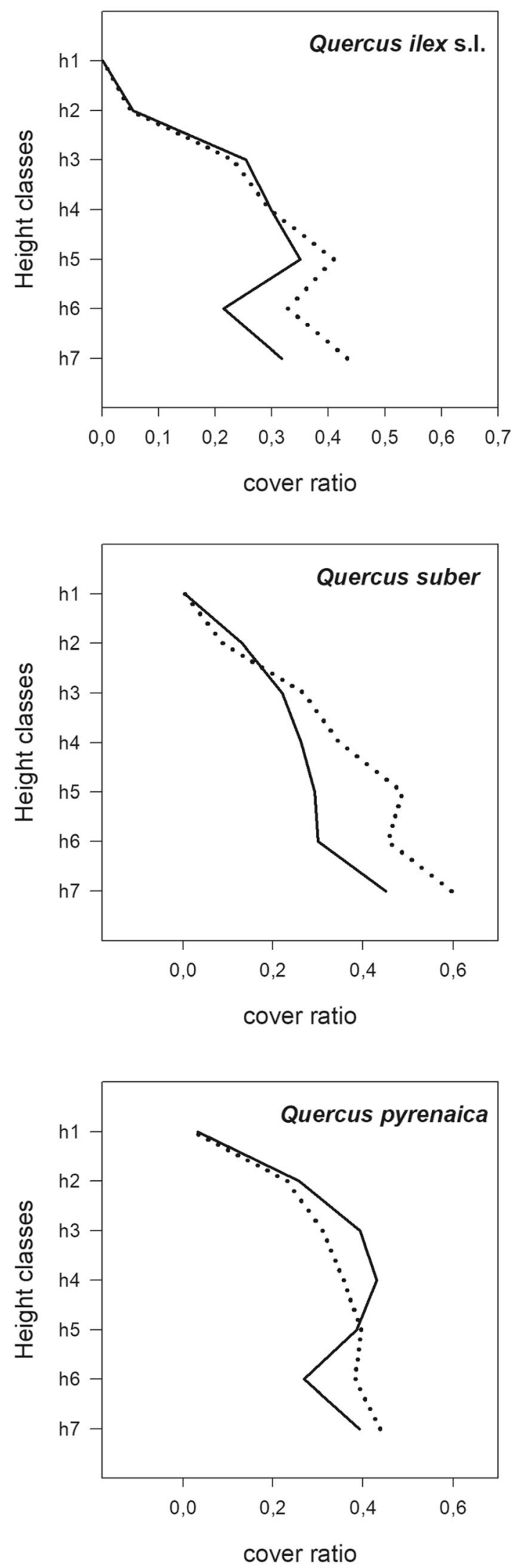
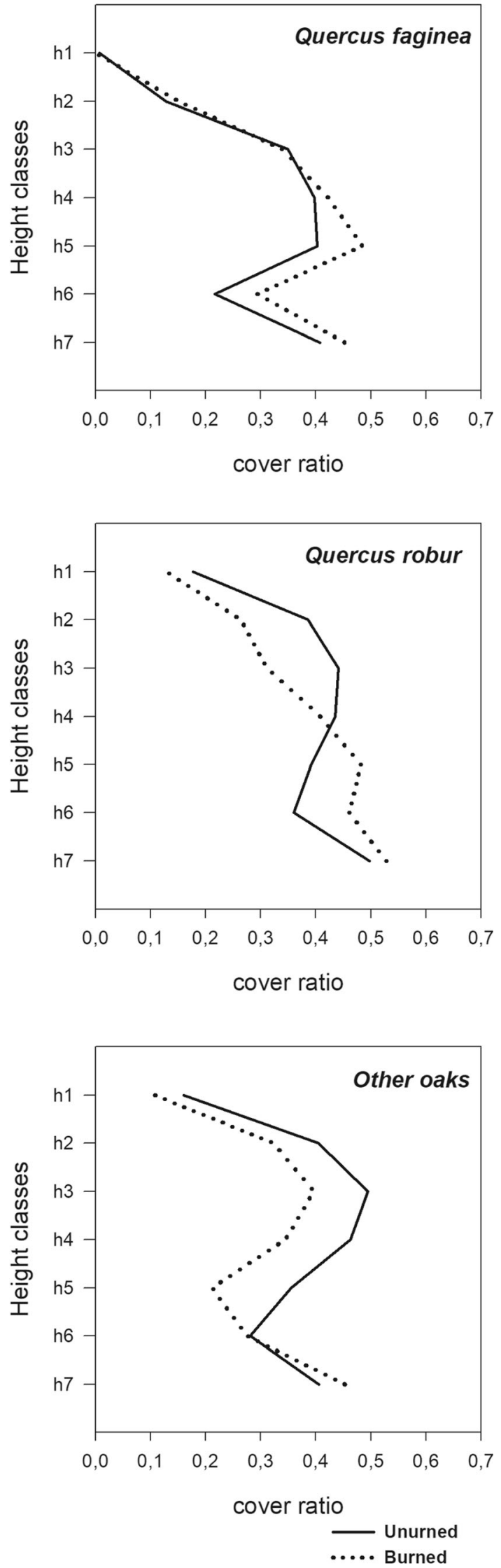

Fig. 5 continued. 

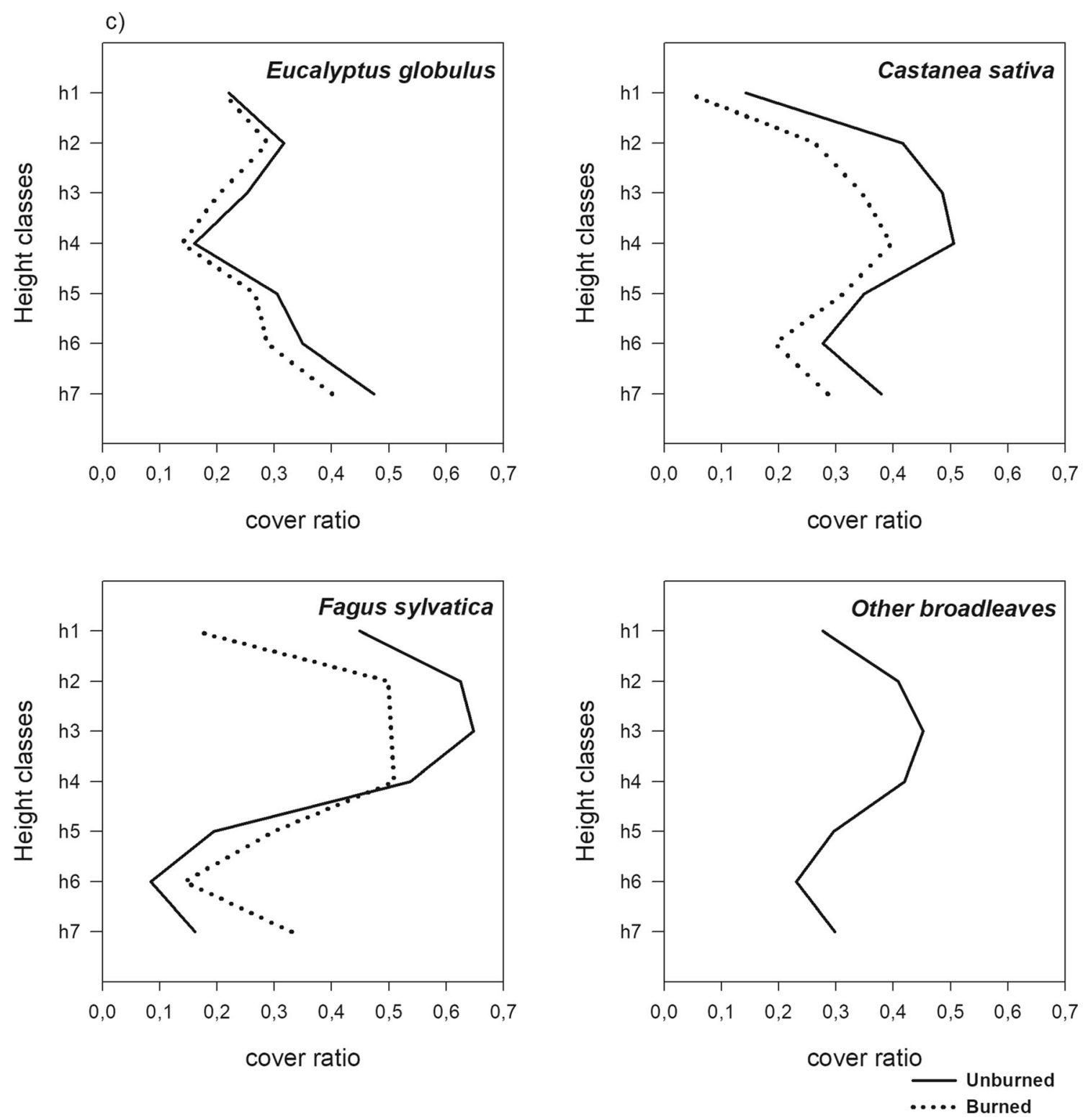

Fig. 5 continued. 
Acknowledgments The authors wish to thank Roberto Vallejo and Vicente Sandoval of the Spanish Ministry of Agriculture, Food and Environment for kindly providing access to the full Spanish NFI datasets and to Paula Sarmento and Conceição Ferreira of the Portuguese National Forest Services for kindly providing access to the Portuguese NFI datasets. We also want to express our thanks to the TRAGSA field teams of the Spanish National Forest Inventory.

Contribution of the co-authors Leónia NUNES: experimental design, data analysis and elaboration of the paper.

Juan ÁLVAREZ-GONZÁLEZ: experimental design and writing the paper.

Iciar ALBERDI: experimental design and writing the paper.

Vasco SILVA: experimental design and writing the paper.

Marta ROCHA: experimental design and writing the paper.

Francisco CASTRO REGO: experimental design, data analysis and writing the paper.

Funding The research was funded by the project DIABOLO (European Union's Horizon 2020 research and innovation programme under grant agreement no. 633464).

Data availability The datasets generated and/or analysed during the current study are available from the corresponding author on reasonable request. The authors are considering to make the new dataset generated during this study available in a public repository upon acceptance from Spanish and Portuguese NFIs responsible and co-authors.

\section{Compliance with ethical standards}

Conflict of interest The authors declare that they have no conflict of interest.

Publisher's note Springer Nature remains neutral with regard to jurisdictional claims in published maps and institutional affiliations.

\section{References}

AFN (2010) Inventário Florestal Nacional, Portugal Continental-IFN5 2005-2006. Relatório Final. Autoridade Florestal Nacional, Lisboa AFN (2009) Instruções para o trabalho de campo do Inventário Florestal Nacional-IFN 2005/2006. Autoridade Florestal Nacional, Direcção Nacional de Gestão Florestal, Lisboa

Alberdi Asensio I, Condés Ruiz S, Millán J, et al (2010) National Forest Inventories Report, Spain. In: Tomppo E, Gschwantner, T, Lawrence M, McRoberts R (eds) National Forest Inventories. Pathways for common reporting. Springer, pp 529-540

Alberdi I, Cañellas I, Vallejo Bombín R (2017) The Spanish National Forest Inventory: history, development, challenges and perspectives. Pesqui Florest Bras 37(91):361-368. https://doi.org/10.4336/2017. pfb.37.91.1337

Alberdi I, Hernandez L, Condes S, Cañellas I (2016) Spain. In: Vidal C, Alberdi I, Hernández L, Redmond J (eds) National Forest Inventories. Assessment of wood availability and use. Springer, pp 749-769

Álvarez-González JG, Cañellas I, Alberdi I, Gadow KV, Ruiz-González AD (2014) National Forest Inventory and forest observational studies in Spain: applications to forest modeling. For Ecol Manag 316: 54-64. https://doi.org/10.1016/j.foreco.2013.09.007

Alvarez A, Gracia M, Vayreda J, Retana J (2012) Patterns of fuel types and crown fire potential in Pinus halepensis forests in the Western Mediterranean Basin. For Ecol Manag 270:282-290. https://doi.org/ 10.1016/j.foreco.2011.01.039
Barreiro S, Godinho Ferreira P, Azevedo A (2010) Portugal. In: Tomppo E, Gschawantner T, Mawrence M, MacRoberts RE (eds) National Forest Inventories: pathways for common reporting. Springer, pp 437-464

Botequim B, Fernandes PM, Garcia-Gonzalo J, Silva A, Borges JG (2017) Coupling fire behaviour modelling and stand characteristics to assess and mitigate fire hazard in a maritime pine landscape in Portugal. Eur J For Res 136:527-542. https://doi.org/10.1007/ s10342-017-1050-7

Castroviejo S et al. (2015) (coord. gen.) 1986-2015. Flora iberica 1-9, 10-16(1), 17-18, 20-21. Real Jardín Botánico CSIC, Madrid

CEABN (2013) Fireland-Efeitos do fogo sobre a dinâmica da vegetação à escala da paisagem em Portugal. FCT Project PTDC/AGR-CFL/ 104651/2008, Lisboa

Confalonieri UEC, Neto CC (2012) Diversity of mosquito vectors (Diptera: Culicidae) in Caxiuanã, Pará, Brazil. Interdiscip Perspect Infect Dis 2012:1-8. https://doi.org/10.1155/2012/741273

Cruz MG, Alexander ME, Wakimoto RH (2003) Assessing canopy fuel stratum characteristics in crown fire prone fuel types of western North America. Int J Wildland Fire 12:39-50. https://doi.org/10.1071/ WF02024

DGF (1985) Distribuição da Floresta em Portugal Continental, Áreas Florestais por Distritos, informação disponível em 1984. Estudos e Informação número 297. Direcção-Geral das Florestas, Lisboa

DGF (1989) Distribuição da Floresta em Portugal Continental, Áreas Florestais por Distritos, informação disponível em 1989. Estudos e Informação número 299. Direcção-Geral das Florestas, Lisboa

DGF (1990) Inventário Florestal do Sobreiro. Estudos e Informação 300. Direcção-Geral das Florestas, Lisboa

DGF (2001) InventárioFlorestal Nacional. Portugal Continental. $3^{\mathrm{a}}$ Revisão. 1995-1998. Direcção-Geral das Florestas, Lisboa

DGF (1999) Manual de Instruções para o Trabalho de Campo do Inventário Florestal Nacional. Direcção Geral das Florestas, Lisboa

DGRF (2006) Estratégia Nacional Para as Florestas. Direcção-Geral dos Recursos Florestais, Lisboa

DGSFA (1966) Inventário Florestal Nacional do Norte do Tejo. DirecçãoGeral dos Serviços Florestais e Aquícolas, Lisboa

DGSFA (1968) Inventário Florestal. Memória. Direcção-Geral dos Serviços Florestais e Aquícolas., Lisboa

DGSFA (1971) Inventário Florestal: Áreas, Existências e Estimativas de produção. Direcção-Geral dos Serviços Florestais e Aquícolas., Lisboa

DGSFA (1965-1966) Inventário Florestal Nacional do Sul do Tejo. Direcção-Geral dos Serviços Florestais e Aquícolas, Lisboa

FAO (2004) Global Forest Resources Assessment Update 2005. Terms and definitions (final version). Forest Resources Assessment Programme. Working paper 83/E. Forest Department Food and Agriculture Organization of the United Nations, Rome

Fernandes P, Luz A, Loureiro C, Ferreira-Godinho P, Botelho H (2006) Fuel modelling and fire hazard assessment based on data from the Portuguese National Forest Inventory. For Ecol Manag 234:S229. https://doi.org/10.1016/j.foreco.2006.08.256

Fernandes PM (2009) Combining forest structure data and fuel modelling to classify fire hazard in Portugal. Ann For Sci 66:415. https://doi. org/10.1051/forest/2009013

Fernández-Alonso JM, Alberdi I, Álvarez-González JG, Vega JA, Cañellas I, Ruiz-González AD (2013) Canopy fuel characteristics in relation to crown fire potential in pine stands: analysis, modelling and classification. Eur J For Res 132:363-377. https://doi.org/10. 1007/s10342-012-0680-Z

FOREST EUROPE (2015a) State of Europe's forests 2015. Forest Europe, Liaison Unit Madrid

FOREST EUROPE (2015b) Goals for European forests and the European 2020 targets for forests. Ministerial Conference on the Protection of Forests in Europe, Madrid, Spain

Gómez-Vázquez I, Fernandes PM, Arias-Rodil M, Barrio-Anta M, Castedo-Dorado F (2014) Using density management diagrams to 
assess crown fire potential in Pinus pinaster Ait. stands. Ann For Sci 71:473-484. https://doi.org/10.1007/s13595-013-0350-4

González-Ferreiro E, Arellano-Pérez S, Castedo-Dorado F, Hevia A, Vega JA, Vega-Nieva D, Álvarez-González JG, Ruiz-González AD (2017) Modelling the vertical distribution of canopy fuel load using national forest inventory and low-density airbone laser scanning data. PLoS One 12:1-21. https://doi.org/10.1371/journal.pone.0176114

González JR, Palahí M, Trasobares A, Pukkala T (2006) A fire probability model for forest stands in Catalonia (north-east Spain). Ann For Sci 63(2):169-176. https://doi.org/10.1051/forest

Hardy CC, Schmidt KM, Menakis JP, Sampson RN (2001) Spatial data for national fire planning and fuel management. Int J Wildland Fire 10:353-372

ICNF (2013) IFN6 - Áreas dos usos do solo e das espécies florestais de Portugal continental em 1995, 2005 e 2010. Resultados preliminares. Instituto da Conservação da Natureza e das Florestas, Lisboa

ICNF (2017) $10^{\circ}$ Relatório provisório de incêndios florestais - 2017: 01 de Janeiro a 31 de Outubro. Departamento de Gestão de Áreas Públicas e de Proteção. Instituto da Conservação da Natureza e das Florestas, Lisboa

IEPNB (2016) Criteria and Indicators for sustainable forest management in Spanish forests. Ministerio de Agricultura y Pesca, Alimentación y Medio Ambiente (ed). http://www.mapama.gob.es/es/ biodiversidad/temas/inventarios-nacionales/iepnb_2016_tcm7471246.pdf, Madrid. Accessed 08 Oct 2017

INE (2001) Recenseamento Geral da População e Habitação (Resultados Definitivos). Instituto Nacional de Estatística, Lisboa

Keane RE, Burgan RE, Van Wagtendonk JW (2001) Mapping wildland fuels for fire management across multiple scales: integrating remote sensing, GIS, and biophysical modeling. Int J Wildland Fire 10:301319. https://doi.org/10.1071/WF01028

Keeley JE, Bond WJ, Bradstock RA et al (2012) Fire in Mediterranean ecosystems: ecology, evolution and management. Cambridge University Press

Keyes CR, O'Hara KL (2002) Quantifying stand targets for silvicultural prevention of crown fires. West J Appl For 17:101-109

Lavorel S, Flannigan MD, Lambin EF, Scholes MC (2007) Vulnerability of land systems to fire: interactions among humans, climate, the atmosphere, and ecosystems. Mitig Adapt Strateg Glob Chang 12: 33-53. https://doi.org/10.1007/s11027-006-9046-5

Lentile LB, Smith FW, Shepperd WD (2006) Influence of topography and forest structure on patterns of mixed severity fire in ponderosa pine forests of the South Dakota Black Hills, USA. Int J Wildland Fire 15:557-566. https://doi.org/10.1071/WF05096

MAGRAMA (2015) Los Bosques y la Biodiversidad frente al cambio climático: Impactos, Vulnerabilidad y Adaptación en España. In: Herrero A, Zavala M (eds). Ministerio de Agricultura, Alimentación y Medio Ambiente. http://www.mapama.gob.es/es/cambioclimatico/publicaciones/publicaciones/bosques-biodiversidadfrente-al-cc_tcm7-404996.pdf, Madrid

MAPAMA (2017a) Estadística general de incendios forestales. Ministerio de Agricultura y Pesca, Alimentación y Medio Ambiente http://www.mapama.gob.es/es/desarrollo-rural/ estadisticas/avanceinformativo1 eneroa31 dediciembrede 2017 tcm7-358485.pdf. Accessed 5 Sept 2017

MAPAMA (2017b) Información resumida de los incendios forestales en España. Ministerio de Agricultura y Pesca, Alimentación y Medio Ambiente. http://www.mapama.gob.es/es/desarrollo-rural/ estadisticas/tripticoincendios-junio2015v6 tcm7-462270.pdf. Accessed 5 Sept 2017

MAPAMA (2017c) Los incendios forestales en España. Decenio 2001-2010. Ministerio de Agricultura y Pesca, Alimentación y Medio Ambiente. http:/www.mapama.gob.es/es/desarrollo-rural/estadisticas/ incendiosforestales2001-2010finalmod1_tcm7-349255.pdf. Accessed 5 Sept 2017

MCPFE (2003a) Improved pan-European indicators for sustainable forest management. MCPFE Expert Level Meeting, 7-8 October 2002. Ministerial Conference on the Protection of Forests in Europe, Vienna

MCPFE (2003b) Implementation of MCPFE commitments: national and pan-European activities 1998-2003. Ministerial Conference on the Protection of Forest in Europe, Vienna

Pedroso-de-Moraes C, Prezzi LE, De Souza-Leal T et al (2015) Edge effect on orchids of a fragment of semi-deciduous seasonal forest in the southeast of Brazil. Iheringia - Ser Bot 70:115-127

Pereira JS, Pereira JMC, Rego F et al (2006a) Incêndios florestais em Portugal: caracterização, impactes e prevenção. Instituto Superior de Agronomia, Lisboa

Pereira LS, Louro V, do Rosário L, Almeida A (2006b) Desertification, territory and people, a holistic approach in the Portuguese context. In: Kepner WG, Rubio JL, Mouat DA, Pedrazzini F (eds) Desertification in the Mediterranean Region. A security issue. Springer Netherlands, Dordrecht, pp 269-289

Pollet J, Omi PN (2002) Effect of thinning and prescribed burning on crown fire severity in ponderosa pine forests. Int J Wildland Fire 11: 1-10. https://doi.org/10.1071/WF01045

Rego F, Catry FX, Montiel C, Karlsson O (2013) Influence of territorial variables on the performance of wildfire detection systems in the Iberian Peninsula. For Policy Econ 29:26-35. https://doi.org/10. 1016/j.forpol.2012.11.007

do Rosário L (2004) Indicadores de Desertificação para Portugal Continental. Direcção-Geral dos Recursos Florestais, Lisboa

Ruiz-González AD, Álvarez-González JG (2011) Canopy bulk density and canopy base height equations for assessing crown fire hazard in Pinus radiata plantations. Can J For Res 41:839-850. https://doi. org/10.1139/x10-237

San-Miguel-Ayanz J, Moreno JM, Camia A (2013) Analysis of large fires in European Mediterranean landscapes: lessons learned and perspectives. For Ecol Manag 294:11-22. https://doi.org/10.1016/j.foreco.2012.10. 050

San-Miguel-Ayanz J, Schulte E, Schmuck G, et al (2012) Comprehensive monitoring of wildfires in Europe: the European forest fire information system (EFFIS). In: Approaches to managing disaster-assessing hazards, emergencies and disaster impacts. InTech

Silva JS, Moreira F, Vaz P, Catry F, Godinho-Ferreira P (2009) Assessing the relative fire proneness of different forest types in Portugal. Plant Biosyst 143:597-608. https://doi.org/10.1080/11263500903233250

Tomé M, Luís JS, Monteiro ML, Oliveira AC (1999) Mixed-species forests in Portugal. Present and future research strategies for management models development. In: Olsthoorn, A.F.M., Bartelink, H.H., Gardiner, J.J., Pretzsch, H., Hekhuis, H.J., Franc A (ed) Management of mixed-species forest: silviculture and economics. DLO Institute for Forestry and Nature Research (IBN-DLO), Wageningen, pp 175-185

Tomppo E, Gschwantner T, Lawrence M, McRoberts (2010) National forest inventories: pathways for common reporting. Natl for invent pathways common report 612 . doi: https://doi.org/10.1007/978-90-481-3233-1

Vidal C, Alberdi I, Redmond J, Vestman M, Lanz A, Schadauer K (2016) The role of European National Forest Inventories for international forestry reporting. Ann For Sci 73:793-806. https://doi.org/10.1007/ s13595-016-0545-6

Watt A (2004) Biodiversity assessment. Final report of the bioassess project. In: http://www.isa.ulisboa.pt/ceabn/uploads/docs/projectos/ bioassess/Final_Reportbioassess.pdf. Accessed in 22 Nov 2017

Winter S, Chirici G, McRoberts RE et al (2008) Possibilities for harmonizing national forest inventory data for use in forest biodiversity assessments. Forestry 81:33-44. https://doi.org/10.1093/forestry/ cpm042 